\title{
Internalisasi Nilai Kedisiplinan Santri melalui Kepemimpinan Kiai di Pondok Pesantren Darul Falah dan Pondok Pesantren Nurul Huda Al-Islami Lembang
}

\author{
Oke Prasetyo ${ }^{1}$, Dadi Permadi ${ }^{2}$, Ujang Cepi Barlian ${ }^{3}$ \\ 1,2,3Sekolah Pascasarjana, Universitas Islam Nusantara Bandung, Indonesia \\ E-mail: okeprasetyo21101980@gmail.com, dadipermadi11@gmail.com, ujangcepibarlian@gmail.com
}

\begin{abstract}
Article Info
Abstract

Article History

Received: 2022-02-03

Revised: 2022-02-22

Published: 2022-03-01

In managing an educational institution, in particular, it must have good planning, in this case the planning of the Islamic Boarding School Leader makes a curriculum to increase the level of discipline of the students. In its implementation, the Kiai at the Darul Falah Islamic Boarding School in Cihampelas and the Nurul Huda Al-Islami Islamic Boarding School in Lembang, West Bandung Regency, directly guided and

Keywords:

Discipline;

Santri;

Pesantren;

Kiai. evaluated the Santri and the Asatidz Council. The example they put forward in boosting the discipline of their students. The general conclusion is that the two kiai in the two Islamic boarding schools, in addition to the examples provided, are also accompanied by openness to all inputs and suggestions, making the students close to full compliance which makes the two kiai able to instill disciplined values in their respective students. This is supported by the implementation of the curriculum that has been designed and implemented consistently. In the implementation of character education, students are carried out together which are well organized, so that any obstacles that arise are easy to pass and even able to jump-start the quality of education in their respective Islamic boarding schools. Evaluation is important in the implementation of all programs that have been carried out so that there is progress in the results of the program. For this reason, the suggestion from the author is to carry out character education, in this case, to increase student discipline in a well-programmed manner according to their respective duties and responsibilities.
\end{abstract}

\begin{tabular}{l}
\hline Artikel Info \\
\hline Sejarah Artikel \\
Diterima: 2022-02-03 \\
Direvisi: 2022-02-22 \\
Dipublikasi: 2022-03-01
\end{tabular}

Kata kunci: Disiplin;

Santri;

Pesantren;

Kiai.

\begin{abstract}
Abstrak
Dalam mengelola sebuah Lembaga Pendidikan khususnya harus memiliki perencanaan yang baik, dalam hal ini perencanaan Pimpinan Pondok Pesantren membuat kurikulum untuk meningkatkan tingkat kedisiplinan santrinya. Dalam pelaksanaannya Kiai di Pondok Pesantren Darul Falah Cihampelas dan Pondok Pesantren Nurul Huda AlIslami Lembang Kabupaten Bandung Barat turun langsung membimbing dan mengevaluasi para Santri dan Dewan Asatidz. Kerteladanan yang mereka kedepankan dalam mendongkrak peningkatan kedisiplinan para santrinya. Kesimpulan secara umum adalah kedua Kiai di kedua Pondok Pesantren tersebut disamping keteladanan yang diberikan juga diiringi dengan keterbukaan terhadap semua masukan dan saran menjadikan santri dekat dengan penuh kepatuhan yang menjadikan kedua Kiai tersebut mampu menanamkan nilai-nilai kedisplinan kepada santrinya masing-masing. Hal tersebut didukung dengan pelaksanaan kurikulum yang telah dirancang dilaksanakan dengan konsisten. Dalam pelaksanaan Pendidikan karakter santri dilakukan secara Bersama yang teroganisir dengan baik, sehingga setiap kendala yang muncul mudah dilewati bahkan mampu melejitkan kualitas Pendidikan di Pesantrennya masing-masing. Evaluasi merupakan hal yang penting dalam pelaksanaan semua program yang telah dilakukan agar ada progresitas dalam hasil dari program tersebut. Untuk itu saran dari penulis adalah laksanakan Pendidikan karakter dalam hal ini peningkatan kedisiplinan santri secara terprogram dengan baik sesuai tupoksinya masing-masing.
\end{abstract}

\section{PENDAHULUAN}

Pendidikan Nasional memiliki peranan yang sangat penting dalam membentuk karakter, peradaban dan identitas diri yang jelas untuk mencerdaskan kehidupan bangsa, hal tersebut bertujuan untuk mengembagkan potensi dan kemampuan peserta didik agar menjadi orang yang beriman kepada Allah. Selain itu Pendidikan mampu menjadikan anak didik memiliki akhlaq yang baik, sehat jasmani dan ruhani, memiliki keilmuan yang mumpuni, kreatif, cakap, mandiri, dan memiliki dedikasi yang tinggi untuk memajukan bangsa dan negara serta ber-tanggungjawab, hal ini sejalan dengan Undang-undang Sistem Pendidikan Nasional, No. 20 Tahun 2003, Bab 1, Pasal 1, ayat 1, bahwa: "Pendidikan adalah 
usaha sadar dan terencana untuk mewujudkan suasana belajar dan proses agar peserta didik secara aktif mengembangkan potensi dirinya untuk memiliki kekuatan spiritual, keagamaan, pengendaliaan diri, kepribadiaan kecerdasan, akhlak mulia, serta keterampilan yang diperlukan dirinya, Bangsa dan Negara, namun pada kenyataannya, Pendidikan di Negara Kesatuan Republik Indonesia ini kehilangan ruhnya. Kurangnya rasa hormat, sopan santun, sapa, salam, ramah, kompak, tanggungjawab, gotong royong menjadi bukti nyata degradasi moral anak bangsa ini.

Tersedianya teknologi yang canggih menjadikan segala sesuatunya mudah masuk dan mudah di akses kapanpun, dimanapun dan oleh siapaun, namun disamping itu tekhnologi yang berkembang saat ini melalui berbagai macam platform media sosial dapat digunakan oleh semua kalangan dari mulai siswa SD sampai dengan orang dewasa, pesatnya penggunaan media sosial memudahkan semua penggunanya mengakses hal-hal yang baik ataupun tidak baik dan itu semua dapat mempengaruhi penggunanya. Hal ini pun terjadi kepada semua orang khususnya remaja bahwa, didapati banyak penyimpangan moral, pertahanan diri yang kurang, mempermudah hancurnya akhlaq remaja Indoneisa khususnya, dengan demikian Pendidikan karakter menjadi hal yang penting untuk dapat merubah menjadi seperti semula. Hilangnya nilai-nilai pendidikan karakter saat ini sangat memprihatinkan, dikarenakan hal itu, maka pendidikan karakter sangat penting diberikan kepada santri di Pondok Pesantren demi terwujudnya tujuan Pendidikan Nasional dan membentuk karakter santri menjadi pribadi yang Islami (syakhsyah Islamiyah). Untuk terwujudnya hal itu, maka harus ada sinergisitas antara Pondok Pesantren, Guru, Santri dan Orang tua santri, pendidikan karakter yang diperlukan di Pondok Pesantren ini adalah karakter kedisiplian beramaliah, beribadah, dan belajar.

Menurut Djamarah (dalam Afiati 2018: 3) Disiplin merupakan salah satu unsur kualitas sumber daya manusia, disiplin dapat membuat seseorang memiliki perasaan taat dan patuh terhadap nilai yang diyakini sehingga lebih bertanggung jawab untuk dapat mengatur tatanan kehidupan pribadi dan kelompok, dalam meningkatkan kualitas Pendidikan maka dibutuhkan sebuah manajemen dalam pendidikan. Hal itu berlaku agar tercapai tujuan yang dirancang sesuai dengan harapan yang diinginkan, menurut Arifin (2013: 1) Manajemen
Pendidikan adalah proses pengemabangan kegiatan Kerjasama sekelompok orang untuk mencapai pendidikan yang telah ditetapkan. Proses pengendalian kegiatan kelompok tersebut mencakup perencanaan (planning), peng-organisasian (organizing), penggerakan (actuating) dan pengawasan (controlling) sebagai suatu proses untuk menjadikan visi menjadi aksi, untuk dapat memfungsikan setiap elemen dalam teori manajemen tersebut membutuhkan sebuah tim dan dalam menjalankan roda organisasi harus dapat mengoptimalkan kinerja tim, sudah barang tentu hal yang demikian membutuhkan sosok pemimpin yang mampu mengatur arah kinerja yang dipimpinnya.

Secara umum kita semua tahu bahwa pendidikan formal adalah pendidikan yang dilaksanakan oleh sekolah secara formal. Pendidikan informal adalah Pendidikan yang dilasanakan di dalam lingkungan keluarga, sedangkan pendidikan non-formal, merupakan proses pendidikan yang dilakukan diluar dari kedua Pendidikan tersebut di atas. Pesantren merupakan Lembaga Pendidikan Islam yang memberlakukan konsep Boarding School yang bersifat tradisional sebagai pedoman hidup dan memahami hakekat agama (tafaqquh fi al-din) dalam bermasyarakat, pada zaman penjajahan pesantren menjadi basis perjuangan kaum muslimin khususnya dan umumnya masyarakat Indonesia. Masjid, surau atau langar merupakan tempat untuk merencanakan kegiatan yang akan dilakukan, di Pondok Pesantren-pun ditemui banyak permasalahan yang berkaitan dengan tanggungjawab dan kedisiplinan. Tidak terdapat rasa memiliki dalam diri seorang santri akan pesantrennya, maka akan berimbas kepada kondisi dalam pesantren itu sendiri seperti melanggar aturan pesantren, kebersihan pesantren, dan kualitas kehidupan di Pesantren.

Ketertarikan penulis menggali profil kualitas dan pengaruh Kiai di pesantrennya masingmasing dalam meningkatkan kedisiplinan santrisantrinya, adapun kedua Pondok Pesantren itu adalah Pesantren Nurul Huda Lembang Kabupaten Bandung Barat dan Pondok Pesantren Darul Falah Cihampelas Kabupaten Bandung Barat, bukan tanpa kendala mengelola sebuah Lembaga yang majemuk dan banyak orang di dalamnya. Permasalahan yang terjadi dikedua pesantren itu adalah sebagai berikut: 
Tabel 1. Permasalahan yang terdapat pada kedua pesantren

\begin{tabular}{|c|c|c|}
\hline No & Ponpes. Darul Falah & Ponpes. Nurul Huda \\
\hline 1 & $\begin{array}{l}\text { Masih ada santri yang } \\
\text { terlambat melaksa- } \\
\text { nakan pembelajaran. }\end{array}$ & $\begin{array}{l}\text { Belum berdisiplin dalam } \\
\text { penggunaan Bahasa } \\
\text { sehari-hari (Arab dan } \\
\text { Inggris) yang sudah } \\
\text { ditetapkan. }\end{array}$ \\
\hline 2 & $\begin{array}{l}\text { Masih kurangnya tan- } \\
\text { ggungjawab menjaga } \\
\text { dan merawat Keseha- } \\
\text { tan lingkungan sekitar. }\end{array}$ & $\begin{array}{l}\text { Masih adanya santri } \\
\text { yang mencorat- coret di } \\
\text { dinding. }\end{array}$ \\
\hline 3 & $\begin{array}{l}\text { Masih menunda pe- } \\
\text { kerjaan sehingga } \\
\text { menumpuk pada suatu } \\
\text { masa. }\end{array}$ & $\begin{array}{l}\text { Masih adanya santri } \\
\text { yang tidur di dalam } \\
\text { kelas. }\end{array}$ \\
\hline 4 & $\begin{array}{l}\text { Pelanggaran demi pe- } \\
\text { langgaran terhadap } \\
\text { aturan yang telah di- } \\
\text { tetapkan oleh pihak } \\
\text { pesantren masih te-rus } \\
\text { terjadi. }\end{array}$ & $\begin{array}{l}\text { Masih terdapat santri } \\
\text { kabur dari } \\
\text { Pesantrennya. }\end{array}$ \\
\hline 5 & $\begin{array}{l}\text { Sarana pra-sarana yang } \\
\text { tersedia belum terjaga } \\
\text { seutuhnya sehingga } \\
\text { banyak yang rusak dan } \\
\text { tidak terpakai. }\end{array}$ & $\begin{array}{l}\text { Masih terdapat santri } \\
\text { yang masbuk saat } \\
\text { pelaksanaan sholat } \\
\text { secara berjama'ah. }\end{array}$ \\
\hline
\end{tabular}

Seluruh santri di Pondok Pesantren Darul Falah Cihampelas Kabupaten Bandung Barat maupun di Pondok Pesantren Nurul Huda AlIslami Lembang Kabupaten Bandung Barat kesemuanya mondok di asrama yang telah disediakan oleh pihak Pesantren, mereka belajar di sekolah pada pagi hari sampai menjelang petang hari dan dilanjutkan dengan pembelajaran kepesantrenan hingga malam hari.

\section{METODE PENELITIAN}

Jenis penelitian yang digunakan adalah deskriptif kualitatif, penelitian kualitatif merupakan penelitian untuk mengeksplorasi dan memahami makna yang oleh sejumlah individu atau kelompok orang dianggap berasal dari masalah social atau kemanusiaan (Creswell, 2010:4), lebih lanjut Creswell (2010) menjelaskan bahwa proses penelitian kualitatif ini melibatkan upaya-upaya penting, seperti mengajukan pertanyaan-pertanyaan dan prosedurprosedur, mengumpulkan data yang spesifik dari para partisipan, menganalisis data secara induktif mulai dari tema-tema yang khusus ketema-tema umum, dan menafsirkan makna data, adapun teknik pengumpulan data yang digunakan pada penelitian ini adalah observasi, wawancara dan studi dokumentasi. Lokasi penelitian di Pondok Pesan-tren Nurul Huda Al-Islami Lembang Kabupaten Bandung Barat yang beralamat di Kampung Nyalindung Rt. 04 Rw. 08 Desa Cikole Kecamatan Lembang Kabupaten Bandung Barat dan di Pondok Pesantren Darul Falah Cihampelas Kabupaten Bandung Barat yang beralamat di Jalan Raya Cihampelas No.45 Desa Cihampelas Kecamatan Cihampelas Kabupaten Bandung Barat.

\section{HASIL DAN PEMBAHASAN}

\section{A. Hasil Penelitian}

Deskripsi hasil yang diperoleh di Pondok Pesantren Darul Falah Cihampelas dan Pondok Pesantren Nurul Huda Al-Islami Lembang Kabupaten Bandung Barat

Penyusunan kurikulum di pesantren Darul Falah Cihampelas dan pondok esantren Nurul Huda Al-Islami Lembang Kabupaten Bandung Barat menitik beratkan kepada pembentukan karakter atau karakter building Santri, pelaksanaan dari kurikulum tersebut melalui proses penyusunan, penetapan, dan efisiensi sesuai dengan tujuan yang telah ditetapkan, dalam perencanaan penyusunan kurikulum dibuat sesuai dengan kebutuhan belajar Santri. Seluruh santri memiliki kesempatan untuk dapat merubah perilaku mereka yang kedepannya sangat berguna ketika sudah kembali ke masyarakat, hal yang terpenting dan mendasar dalam setiap pembelajaran adalah terletak kepada perencanaan pembelajaran tersebut, perencanaan pembelajaran merupakan salah satu tolak ukur baik atau buruknya kualitas pembelajaran tersebut, jika gagal dalam perencanaan pembelajaran maka kita sudah merencanakan kegagalan dalam pembelajaran tersebut. Pesantren Darul Falah dan Pesantren Nurul Huda Al-Islami merupakan salah satu lembaga pendidikan non formal, memiliki ciri khas dalam menyusun perencanaan pembelajaran.

Kompetensi yang dibentuk di pesantren ini adalah menjadikan santri yang berakhlakul karimah, untuk itu disusunlah kurikulum yang menyediakan materi-materi berkaitan dengan tingkat kedisiplinan santri melalui kitab kuning ataupun kitab-kitab lainnya termasuk didalamnya adalah kitab Ta'lim almuta'alim, dalam pembentukan karakter disiplin santri di Pondok Pesantren Darul Falah dan Pondok Pesantren Nurul Huda Al-Islami, dewan asatidz bukan hanya mengajar tapi mendidik yang salah satunya adalah melalui keteladanan dari para pendidik dan pimpinan pondok pesantren. Materi-materi teori itu diambil di dalam beberapa kitab diantaranya adalah Jurumiyah, Nadhom Maqshud, Nadhom Imrity, Tashrif Kailani, dan Alfiyah. Sedangkan 
untuk prakteknya ilmu-ilmu yang telah diterima diimplementasikan melalui beberapa kegiatan seperti salat berjamaah, mengikuti kajian-kajian, menghormati Guru dan orang yang lebih tua, menghargai sesama Santri, dan lain sebagainya.

Pelaksanaan pembiasaan nilai-nilai kedisiplinan dalam aktivitas sehari-hari santri di Pondok Pesantren Darul Falah dan Pondok Pesantren Nurul Huda Al-Islami sangat dipengaruhi oleh keteladanan dari Kiai, asatidz dan pengurus pesantren, pembentuzkan karakter Santri terjadi melalui aktivitas kegiatan para santri selama berada di pondok pesantren. Interaksi santri dengan Kiai, dewan asatidz dan pengurus pesantren selama di lingkungan Pondok Pesantren sangat berpengaruh untuk menguatkan good character Santri. Dari hasil observasi dan wawancara, Pondok Pesantren Darul Falah dan Pondok Pesantren Nurul Huda Al-Islami menguatkan pendidikan karakter kepada para santrinya dalam kegiatan sehari-harinya, karena mereka selama 24 jam tinggal di lingkungan Pondok Pesantren dalam pantauan guru-gurunya, sehingga mereka dapat merasakan langsung ajaran-ajaran yang diajarkan oleh Kiai atau Ustadz-Ustadz yang mengajar kitab-kitab kuning. Dari hasil observasi penelitian ini didapatkan aktivitas yang menguatkan karakter santri adalah kegiatan shalat berjamaah, etika bergaul santri kepada sesama warga Pondok Pesantren, etika berpakaian dan piket kebersihan harian ataupun mingguan.

Sarana prasarana merupakan hal yang sangat penting untuk berbagai macam lembaga, terlebih lagi lembaga pendidikan kan yang melibatkan banyak orang maka dibutuhkan sarana prasarana yang memadai agar proses pembelajaran berjalan dengan baik, tidak sedikit lembaga pendidikan yang memiliki kendala dalam sarana dan prasarana sehingga terkendala pula dalam pelaksanaan pembelajaran dan pendidikan karakter. Berdasarkan hasil wawancara salah satu kendala dalam penerapan pembiasaan disiplin Santri adalah sarana prasarana yang belum memadai, hal ini segera diatasi oleh pengurus Pondok Pesantren agar mampu memberikan pelayanan yang terbaik kepada santrisantrinya sehingga proses pembelajaran di kelas ataupun pembiasaan kedisiplinan di aktivitas-aktivitas lainnya di Pondok
Pesantren berjalan dengan baik sebagaimana mestinya.

Kendala lain dari penerapan kedisiplinan ini adalah banyaknya santri yang masih berleha-leha dalam melaksanakan berbagai macam aktivitas yang itu merupakan sebuah pelanggaran dari tata tertib yang telah ditentukan. Hal itu menjadikan para pengurus mengambil sikap yang tegas terhadap setiap pelanggaran dengan menerapkan hukuman yang telah ditentukan, ini semua tidak lain adalah untuk meminimalisir terjadinya pelanggaran dan kegiatan pembiasaan kedisiplinan berjalan dengan baik. Berkat kerjasama dari semua pihak di Pondok Pesantren Darul Falah dan Pondok Pesantren Nurul Huda Al-Islami maka kendala ini lambat laun bisa diperbaiki dengan berbagai macam upaya yang pada akhirnya para santri merasa nyaman dan meningkatkan kualitas pendidikannya hingga mereka memiliki prestasiprestasi dalam bidang akademik ataupun non akademik.

Evaluasi merupakan bentuk penilaian terhadap Tingkat keberhasilan santri mencapai tujuan yang telah ditetapkan dalam sebuah program, evaluasi pembelajaran merupakan salah satu proses kegiatan yang sistematis, terukur, berkelanjutan, dalam aspek pengendalian, penjaminan dan penetapan kualitas pembelajaran terhadap berbagai komponen pembelajaran berdasarkan pertimbangan kriteria tertentu sebagai pertanggungjawaban guru dalam melaksanakan kegiatan belajar mengajar. Dari hasil observasi di lapangan sosok seorang Kiai adalah sosok pemimpin yang lemah lembut namun tegas dalam memutuskan sebuah perkara melalui proses musyawarah. Ketegasan yang diawali dengan sikap lemah lembut membuat seluruh orang yang ada dalam Pesantren tersebut merasa nyaman dengan keputusan yang diambil oleh Beliau melalui musyawarah, sedikit sekali profil pemimpin seperti ini yang mampu menyelesaikan permasalahan yang ada pada lembaganya dengan baik tanpa meninggalkan kesan yang tidak baik terhadap yang dipimpinnya.

\section{B. Pembahasan}

Deskripsi Pembahasan dari hasil Penelitian yang diperoleh di Pondok Pesantren Darul Falah Cihampelas dan Pondok Pesantren Nurul Huda Al-Islami Lembang Kabupaten Bandung Barat 
Aspek penting dan mendasar dalam setiap pembelajaran dimulai dari perencanaan pembelajaran, baik dan buruknya kualitas pelaksanaan pembelajaran salah satu faktornya dipengaruhi oleh perencanaan pembelajaran. Dalam perencanaan pembelajaran di Pondok Pesantren Darul Falah Cihampelas dan Nurul Huda Al-Islami Lembang Kabupaten Bandung Barat lebih mengedepankan pendidikan kedisiplinan Santri, jadi program penyusunan kurikulum pembelajaran pun tidak hanya mengedepankan faktor intelektual saja tapi juga harus bisa membangun ruhaniah Santri, tujuannya agar seorang santri pintar secara keilmuan nya juga baik secara akhlak nya, kurikulum yang disusun dimulai dengan pembagian jenjang pembelajaran di pesantren. Pesantren Darul Falah Cihampelas membagi kedalam tiga jenjang Pendidikan yaitu I'dadiyyah, Ibtida'iyyah, Tsanawiyyah (Aliyyah 1, Aliyyah 2, Aliyyah 3, dan Takhassus). Sedangkan kurikulum yang dibuat di Pondok Pesantren Nurul Huda AlIslami dibagi per jenjang pendidikan formal santri yaitu MTS dan SMA. Adapun pelajaran yang diberikan pada tingkat MTS adalah Tadarus Al-Quran, tahfidz Quran, Ulumul Quran dan praktek Bahasa Arab, sedangkan untuk tingkat SMA yang dipelajari adalah Nahwu dan Sharaf, fiqih, Quran hadis, dan Muhadarah dan untuk Aqidah Akhlak dan Sirah Nabawiyah kedua jenjang sekolah ini mendapatkan materi pembelajaran tersebut. Ada satu materi yang sedang dikembangkan dan sangat berkaitan dengan pembinaan kedisiplinan yaitu materi Shalat Khusyu'.

Untuk pelaksanaan pembiasaan nilai-nilai kedisiplinan pada santri baik di Pondok Pesantren Darul Falah ataupun di Pondok Pesantren Nurul Huda Al-Islami memiliki beberapa kemiripan dilihat dari segi pemberian tanggung jawab ke setiap santri dan juga dilengkapi dengan keteladanan Kiai, Ustadzz dan pengurus pondok pesantren, keberhasilan pelaksanaan pembiasaan nilai kedisiplinan para santri di kedua Pondok Pesantren ini sangat ditentukan oleh pemahaman setiap tugas dari stakeholder yang ada di kedua Pesantren tersebut, setiap stakeholder memiliki tugas dan peranan yang berbeda. Tugas Ustadz adalah memberikan pemahaman lebih mendalam terkait dengan materi materi pembelajaran yang ada, tugas dari pengurus Pondok Pesantren adalah memantau kegiatan sehari-hari santri dari mulai bangun tidur hingga tidur kembali disesuaikan dengan kegiatan-kegiatan yang telah dijadwalkan sebelumnya, sedangkan tugas Kiai adalah disamping memberikan keilmuan kepada para santri juga memanage seluruh stakeholder yang ada pada Pondok Pesantren tersebut dan mengevaluasi setiap program-program yang telah direncanakan baik dari pengurus ataupun terjun langsung kepada santri.

Bentuk pembiasaan penanaman nilai-nilai kedisiplinan pada para santri melalui program salat berjamaah yang wajib diikuti oleh seluruh Santri, disamping itu santri juga memiliki tanggungjawab dari segi kebersihan yaitu dengan mendapatkan jadwal untuk membersihkan lingkungan asrama Pesantren dan juga masjid. Sedangkan di Pondok Pesantren Nurul Huda menambahkan satu program untuk mendisiplinkan para santrinya yaitu dengan program tauhidullah berupa pelatihan salat khusyuk yang dilakukan secara berkala tiap satu pekan sebanyak tiga kali, dalam pelatihan salat khusyuk santri dikenalkan dengan Siapa dirinya dan siapa itu Allah, melalui mempelajari gerak dan bacaan salat memberikan dampak yang cukup signifikan terhadap perubahan diri khususnya adalah kedisiplinan siswa yang telah termotivasi setelah mengikuti pelatihan shalat Khusyu yang rutin dilakukan di Pondok Pesantren Nurul Huda. Namun disamping itu semua yang paling efektif dalam pembelajaran Pendidikan kedisiplinan adalah keteladanan dari para Ustadzz pengurus Pondok Pesantren dan tentunya dari Kiai itu sendiri, hadirnya Kiai, Ustadz dan pengurus pondok dalam salat berjamaah merupakan salah satu cara yang cukup efektif melatih kedisiplinan para santrinya, di samping itu menjadikan teladan dalam menjaga kebersihan di setiap lingkungan dengan cara memungut sampah dan membuang sampah kepada tempatnya juga dilakukan dalam rangka pembiasaan kedisiplinan para santri, selanjutnya adalah penegakan secara kontinyu dan tegas tata tertib yang sudah dibuat dilaksanakan tanpa pandang bulu. Keteladanan para stakeholder dalam menerapkan tata tertib juga menjadi perhatian khusus para santri sehingga mereka patuh dan taat tatkala diingatkan ketika sudah dicontohkan oleh para stakeholder tersebut.

Banyak faktor yang menjadi penghambat dalam melakukan penerapan sikap disiplin seperti faktor internal dan faktor eksternal, 
namun setiap Pondok Pesantren tetap memberlakukan system hukuman bagi para siswa siswi atau santri dan santriwati apabila melakukan pelanggaran kecil sampai pelanggaran besar. Pondok Pesantren pun memiliki tujuan yang jelas sama dengan sekolah lainnya, yaitu menciptakan calon generas bangsa yang mampu memahami ilmu pengetahuan dengan baik dan tidak melupakan ibadah atau agamanya. Maka dengan adanya penerapan sikap disiplin akan membuat anak lebih terarah dan bertanggung jawab, lalu nggapan mengenai bahwa anak yang sekolah di Pondok Pesantren ataupun Sekolah biasa pasti lebih memiliki sikap disiplin adalah salah. Karena Sikap Disiplin dapat di terapkan kepada individu apabila ia memiliki lingkungan yang memang mendukung, memiliki pembina yang memang mengarahkan dan juga kesadaran dari dalam diri individu tersebut.

Dalam penanaman nilai-nilai kedisiplinan santri tidak selamanya berjalan dengan mulus, pasti ada kendala dan tantangan yang dihadapi dalam mendidik kedisiplinan para santri. Begitu pula yang dihadapi oleh Pondok Pesantren Darul Falah Cihampelas dan Pondok Pesantren Nurul Huda Al-Islami Lembang Kabupaten Bandung Barat. Ada kendala-kendala yang dihadapi nya seperti berikut ini:

1) Kurangnya dukungan orang tua ketika santri berada di rumah.

2) Sarana prasarana yang dimiliki kedua Pondok Pesantren tersebut yang kurang memadai.

3) Jumlah pengajar yang tidak seimbang dengan Santri yang mukim.

4) Dan yang paling menonjol adalah lingkungan sekitar Pesantren dapat mempengaruhi keberhasilan pendidikan kedisiplinan para santri.

Dalam melaksanakan evaluasi penanaman kedisiplinan santri melalui kepemimpinan Kiai di Pondok Pesantren Darul Falah Cihampelas dan Pondok Pesantren Nurul Huda Al-Islami Lembang Kabupaten Bandung Barat dilakukan dengan dua hal, yang pertama adalah Evaluasi dalam pembelajaran kitab yang telah disusun dalam kurikulum yang terencana dan terukur serta yang kedua adalah secara personality yang menitikberatkan kepada proses penanaman nilai-nilai kedisiplinan santri di Pondok Pesantren Darul Falah Cihampelas dan Pondok Pesantren
Nurul Huda Al-Islami Lembang Kabupaten Bandung Barat. Pada aspek secara teoritis para santri dievaluasi melalui hafalan kitabkitab yang dipelajari dan juga Alquran yang dihafalnya, maka akan tampak bagi mereka yang berdisiplin mempelajarinya akan sangat baik dalam penguasaannya, sehingga atas dasar itu dapat diperoleh hasil pengukuran tersebut melalui nilai yang diterima yang merupakan bentuk perwujudan tingkah laku atau prestasi, secara umum tes mempunyai dua fungsi yaitu sebagai pengukur terhadap santri dan sebagai pengukur terhadap keberhasilan program pengajaran.

Pada aspek secara personality evaluasi yang dilakukan kan dititikberatkan kepada proses pembentukan kedisiplinan Santri, para santri diberikan tanggung jawab sepenuhnya terhadap diri dan lingkungannya baik dari segi kebersihan ataupun segi ibadah. Kehadiran tepat waktu dalam salat berjamaah merupakan salah satu bentuk penilaian kedisiplinan santri dalam hal ibadah, sholat memberikan banyak pelajaran bagi kita untuk bagaimana kita bisa berdisiplin tepat waktu ataupun mengikuti gerakan salat tanpa harus mendahului imam, sehingga terwujudlah kedisiplinan dalam diri santri tak kalah melaksanakan salat berjamaah. Pada sisi lain akan nampak dari segi kebersihan lingkungan dalam upaya menumbuhkan kedisiplinan Santri. Walaupun dipandang sepele namun tidak pula serta merta memungut sampah yang ada di jalan itu mudah untuk dilakukan, kebiasaan demi kebiasaan lah yang akan membentuk karakter disiplin santri tatkala secara continue menerapkan sistem hidup bersih dalam kehidupan sehari-harinya. Maka dari itu pihak pengurus Pondok Pesantren membuat jadwal piket kebersih-an dalam upaya menumbuhkan kebiasaan berdisiplin di dalam bidang kesehatan lingkungan.

\section{SIMPULAN DAN SARAN}

\section{A. Simpulan}

Dari penelitian yang telah dilaksanakan maka dapat diambil kesimpulan sebagai berikut:

1. Kedua pimpinan Pondok Pesantren memiliki perencanaan dalam mendidik kedisplinan para santrinya dengan membuat sebuah kurikulum. Hal itu dilakukan agar apa yang dilakukannya terukur dan terarah dengan baik sesuai dengan tujuan yang akan dicapainya. 
Dengan kurikulum tersebut maka kedua Pondok Pesantren tersebut dapat menjalankan proses pembelajaran dengan baik sesuai dengan harapan yang diinginkan.

2. Kurikulum yang telah dibuat memudahkan seluruh pengurus dan dewan asatidz dalam melaksanakan pembiasaan kedisiplinan. Hal itu dilakukan melalui beberapa cara diantaranya adalah melalui tata tertib yang telah disusun, melalui kajian-kajian rutin yang dilaksanakan dengan menyisipkan nilai-nilai kedisiplinan yang diharapkan serta melakukan berbagai macam ibadah yang meningkatkan kesadaran dirinya sebagai makhluk yang memiliki tanggungjawab terhadap dirinya masing-masing dalam melaksanakan pembelajaran di Pondok Pesantrennya sesuai dengan aturan yang berlaku.

3. Berbagai macam kendala yang ada merupakan sunnatullah yang pasti terjadi. Namun kemampuan managerial dari pimpinan Pondok Pesantren menjadikan permasalahan yang timbul sebagai landasan untuk melejitkan diri yang memiliki kemampuan pengelolaan yang baik sesuai dengan aturan yang berlaku. Sehingga setiap kendala yang ada dapat dihadapi dengan bersama-sama, yang menajdikan beban yang berat itu menjadi ringan.

4. Akhir dari sebuah kegiatan dalam berorgaanisasi adalah adanya evaluasi. Hal tersebut dilakukan untuk mendapatkan gambaran pencapaian yang telah diraih guna meningkatkan Langkah-langkah kedepannya yang menjadikannya semakin baik. Evaluasi yang dilakukan adalah denga melibatkan seluruh elemen yang ada termasuk orang tua santri untuk permaslaahan secara umum. Namun Ketika ada permasalahan secara internal maka akan diselelsaikan oleh Kiai berserta pengurus dan dewan asatidz.

\section{B. Saran}

Berdasarkan temuan di lapangan dan hasil penelitian yang telah disimpulkan, maka penulis memberikan rekomendasi kepada berbagai pihak sebagai berikut:

1. Dinas Pendidikan.

Hasil penelitian ini diharapakan bisa menjadi masukan bagi pemerintah melalui Dinas Pendidikan sebagai salah satu sumbangsih untuk perbaikan akhlaq pelajar kedepannya, hasil penelitian ini pun diharapkan bisa mempermudah pemerintah dalam menagani degradasi akhlak melalui evaluasi pembinaan akhlak di Pondok Pesantren.

2. Pondok Pesantren

Memberikan manfaat bagi Pondok Pesantren dalam Menyusun kurikulum pembinaan akhlak santri dengan penguatan pembelajaran kedisiplinan yang akan berdampak pada kualitas Pendidikan di Pondok Pesantren.

3. Kiai dan Pengajar di Pondok Pesantren Meningkatkan pelayanan Pendidikan kepada santri, dalam rangka perbaikan kualitas Pendidikan di Pondok Pesantren dalam menghadapi era digitalisasi yang semua dapat masuk dan diakses dengan mudah dengan Sebagian isi konten dapat merusak akhlak remaja pada khususnya, dan juga mampu memberikan masukan untuk menguatkan kurikulum pembinaan karakter khusunya adalah pembiasan kedisiplinan santri

4. Orang Tua

Hasil penelitian ini mampu mendorong dan memotivasi orang tua serta masyarakat sekitar pesantren untuk berperan aktif dalam perbaikan akhlaq santri yang dikemudian hari akan menggantikan orang tua bahkan menjadi pemimpin kelak, dengan Kerjasama ini semoga dapat menghasilkan sosok pemimpin yang baik dan dapat membawa arah peruba-han menuju masyarakat madani.

5. Bagi Santri

Semoga hasil penelitian ini dapat menjadi guidance bagi santri dalam memperbaiki akhlak dan meningkatkan kualitas diri yang siap bersaing di pasar global dalam menjalani kehidupan dikemudian hari, serta menjadikan santri yang memiliki rasa tanggungjawab terhadap diri dalam menjalankan pembelaja-ran di Pondok Pesantren.

6. Peneliti Selanjutnya

Semoga hasil penelitian ini bisa menjadi rujukan untuk penelitian yang selanjutnya yang akan tersempurnakan dengan pemikiran yang baru dan bermanfaat bagi semua pembaca hasil penelitian ini.

\section{DAFTAR RUJUKAN}

Arifin, D. (2013). Leadership Kearifan Lokal dalam Kepemimpinan. Bandung: Pustaka Al-Kasyaf. 
Arifin, D., dkk. (2013). Manajemen Pembiayaan Pendidikan. Bandung: Pustaka Al-Kasyaf.

Arikunto, Suharsimi. (2002). Prosedur Penelitian Suatu Pendekatan. Jakarta: PT. Rineka Cipta.

Barlian, U. C. (2016). Manajemen Strategik Konsep dan Implemantasi. Bandung: Khalifa Insan Cendekia.

Baharuddin, dkk. (2012). Kepemimpinan Pendidikan Islam. Jogjakarta: Ar-Ruzz Media.

Hardani, dkk. (2020). Buku Metode Penelitian Kualitatif dan Kuantitatif. In Husnu Abadi (Ed.). Pustaka Ilmu (1st ed., Issue March). Yogayakarta: Pustaka Ilmu.

Kartono, Kartini. (2016). Pemimpin dan Kepemimpinan. Jakarta: PT. Raja Grafindo Persada.

Kristanto, V. H. (2018). Metodologi Penelitian Pedoman Penulisan Karya Tulis Ilmiah (KTI). Yogyakarta: CV Budi Utama.

Masduki, Duryat. 2016. Kepemimpinan Pendidikan (Meneguhkan Legitimasi dalam Berkontestasi di Bidang Pendidikan). Bandung: CV. Alfabeta.

Moleong, L. J. (2018) Metodologi Penelitian Kualitatif. Bandung: PT. Remaja Rosdakarya

Semiawan, C. R. (2010). Metode Penelitian Kualitatif Jenis, Karakteristik dan Keunggulannya. Jakarta: Grasindo.

Sudaryono. (2014). Leadership: Teori dan Praktek Kepemimpinan, Jakarta Pusat: Lentera Ilmu Cendekia.

Sugiyono. (2016). Metode Penelitian Manajemen. Bandung: CV. Alfabeta.

Permadi, A., dkk. (2016). Pendidikan Karakter Gampang atau Susah? Kab. Bandung Barat: Pustaka Al-Arif.

Uhar Suharsaputra, (2016). Kepemimpinan Inovasi Pendidikan. Bandung: PT. Refika Aditama.

Yusuf, A. M. (2014). Kuantitatif, Kualitatif, \& Penelitian Gabungan. Jakarta: Kencana.

Alfath, K. (2020). Bagaimana proses pendidikan karakter disiplin santri di Pondok Pesantren Al-Fatah Temboro. Jurnal Komunikasi Dan Pendidikan Islam, 9, 125164. https://journal.upy.ac.id/index.php/pkn/a rticle/view/1296/0: 01 Januari 2022

Arifin, Z. (2015). Kepemimpinan Kiai Dalam Ideologisasi Pemikiran Santri Di PesantrenPesantren Salafiyah Mlangi Yogyakarta. Inferensi, 9(2), 351. Diakses melalui https://doi.org/10.18326/infsl3.v9i2.351372: 17 September 2022.

Arnawati, A. (2017). Kedudukan Dan Peran Ulama Dalam Perspektif Alquran (Studi Komparatif. Al-Fath, 11(01).

Assiroji, D. B. (2020). Konsep kaderisasi ulama. 09(01).

Gesi B., Laan R. , F. L. (2019). Manajemen Dan Eksekutif Burhanudin. Jurnal Manajemen, $3(5)$.

Fitri, S. R. A., dkk. (2017). Nilai-Nilai Pendidikan Kedisiplinan Dalam Al-Qur'an Surat Al-'Ashr Ayat 1-3 Menurut Tafsir Al-Maraghi. Jurnal Pendidikan Islam Anak Usia Dini. Diakses melalui https://risetiaid.net/index.php/TA/article/view/109:8 Agustus 2022.

Fridiyanto, dkk. (2020). Konsep Kepemimpinan Dalam Islam. PRODU: Prokurasi Edukasi Jurnal Manajemen Pendidikan Islam.

Hamid, A. (2016). Metode Internalisasi Nilai-nilai Akhlak dalam Pendidikan Agama Islam di SMP Negeri 17 Kota Palu. Diakses melalui http://jurnal.upi.edu/file/06 Metode Inter nalisasi Nilai-Nilai Akhlak Abdul Hamid1.pdf: 14 September 2022.

Hidayat, M. (2017). Model Komunikasi Kiai Dengan Santri di Pesantren. Diakses melalui https://doi.org/10.24329/aspikom.v2i6.8 9.

Jamalulel, H. A. (2018). Peran Kepemimpinan Karismatik Kiai Dalam Pembentukan Karakter Santri di Pondok Pesantren Darul Muttaqien Kabupaten Bogor. Jakarta: UIN Syarif Hidayatullah.

Mayasari, D. (2019). Internalisasi Nilai-Nilai Karakter Peserta Didik Dalam Pembelajaran Tahsin Dan Tahfidz Al-Qur'an Di Ma Tahfizhil Qur'an Yayasan Islamic Centre Sumatera Utara. Diakses https://doi.org/10.30821/ansiru.v3i2.584: 
14 September 2022.

Mukhlis, D. (2015). Pengaruh Gaya Kepemimpinan Kiai Terhadap Sikap Kemandirian Santri (Studi Kasus di Ponpes Al-Amiin Parungpanjang-Bogor) (Issue 109011000027). UIN Syarif Hidayatullah Diakses melalui https://repository.uinjkt.ac.id/dspace/bits tream/123456789/29911/3/DEDEN\%20 MUKHLIS-FITK.pdf: 21 September 2020

Mulyono, H. (2018). Kepemimpinan (Leadership) Berbasis Karakter Dalam Peningkatan Kualitas Pengelolaan Perguruan Tinggi. Diakses melalui https://doi.org/10.32696/jp2sh.v3i1.93: 21 September 2022

Munawaroh. (2019). Kepemimpinan Kiai Dalam Mengembangkan Pondok Pesantren Riyadhul Mubtadi'ien Di Tanjung Rahayu Kec. Way Lima Pesawaran. Universitas Islam Negeri Raden Intan Lampung: Fakultas Dakwah Dan Ilmu Komunikasi Uin Raden Intan Malang. Diakses melalui: http://repository.radenintan.ac.id/6903/1 /SKRIPSI\%20MUNAWAROH.pdf. September 2020.

Munif, M. (2017). Strategi Internalisasi Nilai-Nilai PAI Dalam Membentuk Karakter Siswa. Edureligia; Jurnal Pendidikan Agama Islam. Diakses melalui https://doi.org/10.33650/edureligia.v1i2. 49: 14 September 2022.

Nurkholifah, I. (2018). Penerapan sikap disiplin pada santri dan santriwati di pondok pesantren. Jurnal Kewarganegaraan, 2(2), 46-51.

https://journal.upy.ac.id/index.php/pkn/a rticle/view/1296/0: 14 September 2022.

Nursam, N. (2017). Kelola: Journal of Islamic Education Management. Diakses melalui https://doi.org/10.24256/kelola.v2i2.438: 14 September 2022.

Oktifuadi, K. (2012). Internalisasi Nilai-Nilai Religiusitas Dan Kedisiplinan Siswa Di Smk Negeri Jawa Tengah Kota Semarang. Universitas Islam Negeri Walisongo: Semarang.

$\begin{array}{lllll}\text { Parashakti, } & \text { R. } & \text { D., dkk. (2019). Gaya }\end{array}$
Kepemimpinan dan Motivasi Terhadap Kinerja Karyawan pada Bank BJB Cabang Tangerang. Jurnal Samudra Ekonomi Dan Bisnis. Diakses melalui https://doi.org/10.33059/jseb.v10i1. 1125: 17 September 2022

POHAN, A. S. (2019). Internalisasi Nilai-Nilai Religius Dan Kedisiplinan Ternalisasi NilaiNilai Religius Dan Kedisiplinan Mahasantri Melalui Program Keagamaan Di Lembaga Ahasantri Melalui Program Keagamaan Di Lembaga Ma'had Sunan Ampel Al-Aly Uin Maulana Malik Ibrahim Malang. Universitas Islam Negeri Maulana Malik Ibrahim: Malang..

Pujiastuti, A., dkk. (2016). Pengaruh Gaya Kepemimpinan Dan Disiplin Kerja Terhadap Efektivitas Kerja Guru Di SMK Hidayatul Islam Clarak Kecamatan Leces Kabupaten Probolinggo.

Sahadi, dkk. (2020). Karakter Kepemimpinan Ideal Dalam Organisasi. Moderat: Jurnal Ilmiah Ilmu Pemerintahan.

Salutondok, Y., dkk. (2015). Pengaruh Kepemimpinan, Motivasi, Kondisi Kerja Dan Disiplin Terhadap Kinerja Pegawai Di Kantor Sekretariat DPRD Kota Sorong. Jurnal Emba.

Suteja, J. (2017). Peran Kiai Dalam Pembinaan Mental Spiritual Santri Remaja di Pondok Pesantren Kota Cirebon (Studi Multisitus di Pondok Pesantren Jagasatru, Al-Istiqomah, Ulumuddin, dan Madinatunnajah Kota Cirebon). ORASI: Jurnal Dakwah Dan Komunikasi. Diakses melalui http://www.syekhnurjati.ac.id/jurnal/inde x.php/orasi/article/view/1406: September 2022.

Syafe'i, I. (2017). Pondok Pesantren: Lembaga Pendidikan Pembentukan Karakter. Jurnal Pendidikan Islam.

Sunarto, H. (2018). Peran Kepemimpinan Kiai Dalam Mengembangkan Karakter SantrI (Studi Kasus di Pondok Pesantren KH. Syamsuddin Durisawo Ponorogo). Institut Agama Islam Negeri Ponorogo. Diakses melalui http://digilib.uinsgd.ac.id/id/eprint/2068 7: 10 Oktober 2022. 
Wahid, A. (2013). Peran Ulama dalam Negara di Aceh. Madania. Diakses melalui https://core.ac.uk/download/pdf/287227 872.pdf.

Wahidin, A. (2014). Konsep Ulama Menurut AlQur'an (Studi Analitis atas Surat Fathir Ayat 28). Jurnal Al Tadabbur.

Wirantasa, U. (2017). Pengaruh Kedisiplinan Siswa Terhadap Prestasi Belajar Matematika. Formatif: Jurnal Ilmiah Pendidikan MIPA. Diakses melalui: https://doi.org/10.30998/formatif.v7i1.12 72: 14 September 2022.
Yunus, M. (2015). Manajemen Pesantren Dan Pembentukan Perilaku Santri. Jurnal Kependidikan.

Zulhimma. (2013). Dinamika Perkembangan Pondok Pesantren Di Indonesia.

Undang-Undang Republik Indonesia Nomor 20 Tahun 2003 Tentang Sistem Pendidikan Nasional.

Peraturan Pemerintah RI Nomor 55 Tahun 2007. Pendidikan Agama Dan Pendidikan Keagamaan: Jakarta. 